\title{
Antimicrobial activity of sesquiterpene lactones isolated from traditional medicinal plant, Costus speciosus (Koen ex.Retz.) Sm
}

\author{
Veeramuthu Duraipandiyan ${ }^{1,2}$, Naif Abdullah Al-Harbi', Savarimuthu Ignacimuthu ${ }^{2 *}$ and Chinnasamy Muthukumar ${ }^{1}$
}

\begin{abstract}
Background: Costus speciosus (Koen ex.Retz.) Sm (Costaceae) is an Indian ornamental plant which has long been used medicinally in traditional systems of medicine. The plant has been found to possess diverse pharmacological activities. Rhizomes are used to treat pneumonia, rheumatism, dropsy, urinary diseases, jaundice, skin diseases and leaves are usedto treat mental disorders.
\end{abstract}

Method: Antibacterial and antifungal activities were tested using Disc diffusion method and Minimum Inhibitory Concentration (MIC). Column chromatography was used to isolate compounds from hexane extract. X-ray crystallography technique and GC-MS analysis were used to identify the compounds

Results: Antibacterial and antifungal activities were observed in hexane, chloroform, ethyl acetate and methanol extracts. Hexane extract of C.speciosus showed good activity against tested fungi also. Two sesquiterpenoid compounds were isolated (costunolide and eremanthin) from the hexane extract. Both the compounds did not inhibit the growth of tested bacteria. But, both the compounds inhibited the tested fungi. The compound costunolide showed significant antifungal activity. The MIC values of costunolide were; $62.5 \mu \mathrm{g} / \mathrm{ml}$ against Trichophyton mentagrophytes, $62 . \mu \mathrm{g} / \mathrm{ml}$ against T. simii, $31.25 \mu \mathrm{g} / \mathrm{ml}$ against T. rubrum 296, $62.5 \mu \mathrm{g} / \mathrm{ml}$ against $T$. rubrum 57, $125 \mu \mathrm{g} / \mathrm{ml}$ against Epidermophyton floccosum, $250 \mu \mathrm{g} / \mathrm{ml}$ against Scopulariopsis sp, $250 \mathrm{\mu g} / \mathrm{ml}$ against Aspergillus niger, $125 \mu \mathrm{g} / \mathrm{ml}$ against Curvulari lunata, $250 \mu \mathrm{g} / \mathrm{ml}$ against Magnaporthe grisea.

Conclusion: Hexane extract showed promising antibacterial and antifungal activity. The isolated compound costunolide showed good antifungal activity.

Keywords: Antibacterial, Antifungal, Sesquiterpeneoids, Costus speciosus, Costunolide, Eremanthin, MIC

\section{Background}

Infectious diseases caused by bacteria, fungi, viruses and parasites are still a major threat to public health, despite the tremendous progress in human medicine. Their impact is particularly large in developing countries due to the relative unavailability of medicines and the emergence of widespread drug resistance [1]. Medicinal plants have been a source of bioactive compounds to treat many diseases. Traditionally used medicinal plants produce a variety of compounds with known therapeutic properties [2].

\footnotetext{
*Correspondence: entolc@hotmail.com

2Division of Ethnopharmacology, Entomology Research Institute, Loyola College, Chennai 600 034, India

Full list of author information is available at the end of the article
}

Costus speciosus (Koen ex.Retz.) Sm. (Costaceae, Family)is widely used in Ayurveda. The plant rhizome is bitter, useful in treating burning sensation, constipation, leprosy, worm infection, skin diseases, fever, asthma, bronchitis, inflammations and anaemia $[3,4]$.

C. speciosus leaf infusion or decoction is utilized as a sudorific or in a bath for patients with high fever. Rhizome juice is given with sugar internally to treat leprosy [5]. C. speciosus rhizomes and roots are ascribed to be bitter [6], astringent [7,8], acrid, cooling, aphrodisiac $[9,10]$, purgative and depurative [5], anthelmintic [8,9], antituberculosis [11], spermatorrhoea [12] and antioxidant [13]. Juice of the rhizome is applied on the head for cooling and relief from headache [7]. An alkaloid extracted from C. speciosus rhizomes had papaverine-

\section{Biomed Central}


like smooth muscle relaxant and antispasmodic activities [14]. C. speciosus rhizomes are given to treat pneumonia, rheumatism, dropsy, urinary diseases, jaundice and leaves are given to treat mental disorders; bruised leaves are applied topically to reduce fever; decoction of stem is used to control fever and dysentery [15].

Gupta et al. [16] reported five compounds from the rhizomes of $C$. speciosus tetradecyl 13-methylpentadecanoate, tetradecyl -11-methyltridecanoatc, 14-oxotricosanoic acid, 14-oxoheptacosanoic acid and 15-oxooctacosanoic acid. Triacontanol, $5 \alpha$-stigmast-9 (11) en $-3 \beta$-ol, triacontanoic acid, sitosterol and diosgenin have also been isolated and identified.

Costunolide is a sesquiterpene compound. It has been previously isolated from Saussurea radix and the dried root of S. lappa. It is reported to possess various biological and immunological actions [17-19]. Some kinds of sequiterpene compounds induced apoptosis in cancer cells [20,21], and costunolide also exhibited preventive effects on intestinal carcinogenesis [22]. Sesquiterpene such as costunolide isolated from the leaves of Laurus nobilis was found to potently inhibit blood ethanol elevation in ethanol loaded rats [23,24]. Previously eremanthin was reported to be present in Pterodon pubescens, Eremanthus elaeagnus [25], and n-hexane extract of Larus nobilis leaves [26].

We have already reported the hypoglycemic effect of C. speciosus root crude extracts [27], hypolipidemic effect of costunolide [3], antidiabetic and antilipidemic effect of eremanthin [28] and antioxidant activities of costunolide and eremanthin [29]. We herein report the antimicrobial activity of the crude extracts and two compounds from the rhizome of C. speciosusagainstpathogenic bacteria and fungi.

\section{Methods}

\section{Plant material}

The rhizomes of Costus speciosus (Koen ex.Retz.) were collected from Thandarai, Kanchipuram District, Tamil Nadu, India in 2005. The plant was identified by Dr. D. Narasimman, Department of Botany, Madras Christian College, Chennai, India. The voucher specimen (ERICD-78) was deposited at Entomology Research Institute, Loyola College, Chennai, India.

\section{Preparation of extracts}

The collected rhizomes were shade dried at room temperature and ground in a manual mill. Two kilogram powder was extracted with 6 litre of hexane $(1: 3 ; \mathrm{w} / \mathrm{v})$ for 48 hours. The extract was filtered through a Buchner funnel with Whatman number 1 filter paper. The filtrate was evaporated to dryness under reduced pressure using rotary evaporator at $40^{\circ} \mathrm{C}$. The remains of the plant material were extracted using chloroform, ethyl acetate, methanol and water sequentially in a similar manner using cold percolation method [30]. The yields of extracts were: hexane (25 g); chloroform (22 g); ethyl acetate (28 g), methanol (21 g) and water (19 g).

\section{Isolation and identification of the active compound}

One $\mathrm{kg}$ of coarse powder was soaked in 3 litres of hexane for $72 \mathrm{hrs}$ with intermittent shaking. The filtrate was filtered through Buchner funnel and concentrated using vacuum rotary evaporator at $40^{\circ} \mathrm{C} .25 \mathrm{~g}$ of active crude hexane extract was chromatographed on a silica gel column (Merk 10-200 mesh, 750 gm 3.5 i.d $\times 60$ $\mathrm{cm}$ ) and successively eluted with stepwise gradient of petroleum ether and hexane solvent system (5\%, 10\%, $20 \%, 30 \%, 50 \%, 70 \%$ and 100\%). 116 fractions were collected and each fraction was spotted on a precoated silica gel (Merk-60 F254, $0.25 \mathrm{~mm}$ thick) plate and eluted in Hexane: Ethyl acetate(3:1) and fractions with similar Rf values in TLC pattern were pooled together to get 8 fractions. Fraction 3 was rechromatographed on a silica gel column and eluted with a stepwise gradient of Hexane: Ethyl acetate (9:1) solvent system. An oil substance was obtained in subfraction 1 ; it was identified as eremanthin with a molecular formula $\mathrm{C}_{15} \mathrm{H}_{18} \mathrm{O}_{2}$, molecular weight of $\mathrm{m} / \mathrm{z} 230.13$, m.p $72-75^{\circ} \mathrm{C}$ and $\mathrm{Rf}$ value 0.35 . Based on the GC-MS analysis the fraction 1 was confirmed as Eremanthin [28].

A single pure crystal was obtained in sub fraction 3 eluted with a stepwise gradient of Hexane: Ethyl acetate (8:2) solvent system. The crystal was subjected to crystallographic and spectral analysis for structural determination. The X-ray data for crystal were recorded using Bruker-AX, X-ray diffractometer at the Indian Institute of Technology, Chennai, India. The compound was identified as costunolide [3], with molecular formula $\mathrm{C}_{15} \mathrm{H}_{20} \mathrm{O}_{2}$, molecular weight $\mathrm{m} / \mathrm{z} 234.33$ and m.p 105$108^{\circ} \mathrm{C}$. The Rf value of costunolide was 0.40 .

\section{Tested microorganisms}

The following bacteria and fungi were used for the experiment. Bacteria: Bacillus subtilis MTCC 441, Enterococcus faecalis ATCC 29212, Staphylococcus aureus ATCC 25923, S. epidermidis MTCC 3615, Escherichia coli ATCC 25922, Klebsiella pneumoniae ATCC 15380, Proteus vulgaris MTCC 1771, Pseudomonas aeruginosa ATCC 27853 and Erwinia sp. MTCC 2760; Fungi: T. rubrum MTCC 296, T. rubrum 57/01, T. mentagrophytes 66/01, T. simii 110/02, Epidermophyton floccosum 73/01, Scopulariopsis sp. 101/01 Aspergillus niger MTCC 1344, Botyritis cinerea, Curvularia lunata 46/0, Magnoporthe grisea and Candida albicans MTCC 227. All cultures were obtained from the Department of Microbiology, Christian Medical College, Vellore, Tamil Nadu, India. 


\section{Preparation of inoculums}

The mother culture was streaked on Nutrient Agar medium to obtain isolated colonies. After incubation at $37^{\circ} \mathrm{C} 24 \mathrm{~h}, 4$ or 5 pure colonies were selected with an inoculating needle and transferred to a tube of sterile Mueller-Hinton broth and vortexed thoroughly. The bacterial suspension was equal to the 0.5 McFarland standards. These cell suspensions were diluted with sterile MHB to provide final cell counts of about $10^{4} \mathrm{CFU} /$ $\mathrm{ml}$. The filamentous fungi were grown on Sabouraud Dextrose Agar (SDA) slants at $28^{\circ} \mathrm{C}$ for 10 days and the spores were collected using sterile doubled distilled water and homogenized. Yeast was grown on Sabouraud Dextrose Broth (SDB) at $28^{\circ} \mathrm{C}$ for $48 \mathrm{~h}$.

\section{Disc diffusion assay}

Antibacterial activity was carried out for crude extracts using disc-diffusion method [30]. Petri plates were prepared with $20 \mathrm{ml}$ of sterile Mueller Hinton Agar (MHA) (Hi-media, Mumbai). The test cultures were swabbed on the top of the solidified media and allowed to dry for 10 min. The tests were conducted at three different concentrations of the crude extract (5 mg, $2.5 \mathrm{mg}$ and $1.25 \mathrm{mg}$ per disc). The loaded discs were placed on the surface of the medium and left for $30 \mathrm{~min}$ at room temperature for compound diffusion. Negative control was prepared using respective solvent. Streptomycin $(10 \mu \mathrm{g} / \mathrm{disc})$ was used as positive control. The plates were incubated for $24 \mathrm{~h}$ at $37^{\circ}$ C. Zones of inhibition were recorded in millimeters and the experiment was repeated twice.

\section{Minimum Inhibitory Concentration (MIC)}

The antifungal activity and Minimum Inhibitory Concentration (MIC) were performed using microdilution technique according to the standard reference method [30]. The extracts were dissolved in water $+2 \%$ Dimethyl Sulfoxide (DMSO). The initial concentration of the extract was 1 $\mathrm{mg} / \mathrm{ml}$. Test concentration was serially diluted two-fold in a 96 well plate. Each well was inoculated with $5 \mu$ l of suspension containing $10^{4} \mathrm{CFU} / \mathrm{ml}$ of bacteria and $10^{4}$ spore/ $\mathrm{ml}$ of fungi, respectively. For fungi, the plates were incubated for 24,48 or $72 \mathrm{~h}$ at $27^{\circ}$ up to 9 days for dermatophytes strains; bacteria plates were incubated for $24 \mathrm{~h}$ at $37^{\circ} \mathrm{C}$. MIC was defined as the lowest extract concentration, showing no visible fungal growth after incubation time. $5 \mu \mathrm{l}$ of tested broth was placed on the sterile MHA plates for bacteria and incubated at respective temperature. The MIC for bacteria was determined as the lowest concentration of the compound inhibiting the visual growth of the test cultures on the agar plate.

\section{Antifungal activity of compounds}

The antifungal activity of costunolide and eremanthin isolated from the hexane extract of the rhizome of $C$. speciosus was assessed using standard reference method [30]. $250 \mu \mathrm{g} / \mathrm{ml}$ of the compound was dissolved in water $+2 \%$ Dimethyl Sulfoxide (DMSO). It was serially diluted two-fold. Each well was inoculated with $5 \mu$ l of suspension containing $10^{4}$ spore/ $\mathrm{ml}$ of fungi. The antifungal agents' Ketoconazole and Fluconazole were included in the assays as positive controls.

\section{Results}

Hexane, chloroform, ethyl acetate, methanol and water extracts were screened against bacteria and fungi using disc diffusion method and microdilution technique. Hexane extract inhibited the growth of S. aureus (15 $\mathrm{mm})$ at $2.5 \mathrm{mg} /$ disc, S. epidermidis $(15 \mathrm{~mm})$ at $5 \mathrm{mg} /$ disc and B. subtilis $(12 \mathrm{~mm})$ at $2.5 \mathrm{mg} /$ disc. Chloroform extract inhibited the growth of $S$. aureus $(12 \mathrm{~mm})$ at 2.5 $\mathrm{mg} /$ disc, $S$. epidermidis $(13 \mathrm{~mm})$ at $2.5 \mathrm{mg} / \mathrm{disc}$ and $B$. subtilis $(9 \mathrm{~mm})$ at $5 \mathrm{mg} /$ disc. Ethyl acetate extract inhibited the growth of $S$. aureus $(10 \mathrm{~mm})$ at $5 \mathrm{mg} /$ disc, $S$. epidermidis $(9 \mathrm{~mm})$ at $5 \mathrm{mg} /$ disc and B. subtilis $(9 \mathrm{~mm})$ at $5 \mathrm{mg} /$ disc. Methanol extract showed activity against S. aureus $(14 \mathrm{~mm})$ at $2.5 \mathrm{mg} /$ disc, S. epidermidis $(12$ $\mathrm{mm})$ at $2.5 \mathrm{mg} / \mathrm{disc}$ and $B$. subtilis $(10 \mathrm{~mm})$ at $5 \mathrm{mg} /$ disc. Among the tested extracts the hexane extract showed good activity against only Gram-positive bacteria and tested fungi (Table 1).

Among the tested extracts for antifungal activity the hexane extract significantly inhibited the growth of $T$. mentagrophytes at $0.125 \mathrm{mg} / \mathrm{ml}$, E. floccosum at 0.250 $\mathrm{mg} / \mathrm{ml}$, T. rubrum at $0.125 \mathrm{mg} / \mathrm{ml}$ and $M$. grisea at 0.125 $\mathrm{mg} / \mathrm{ml}$. Other extracts inhibited the growth of fungi moderately. The results are summarized in Table 1.

Based on the above results the hexane extract was subjected to fractionation. Two active sesquiterpenoids, costunolide and eremanthin, were isolated from hexane extract of $C$. speciosus (Figure 1).

The compounds costunolide and eremanthin were tested against bacteria and fungi using micro broth dilution method. Both the compounds inhibited the tested fungi but not the bacteria. The compound costunolide inhibited the growth of fungi such as T. mentagrophytes (62.5 $\mu \mathrm{g} / \mathrm{ml})$, T. simii $(31.25 \mu \mathrm{g} / \mathrm{ml})$, T. rubrum 296 (31.25 $\mu \mathrm{g} / \mathrm{ml})$, T. rubrum $57(62.5 \mu \mathrm{g} / \mathrm{ml})$, E. floccosum $(125 \mu \mathrm{g} / \mathrm{ml})$, Scopulariopsis sp $(250 \mu \mathrm{g} / \mathrm{ml})$, A. niger $(250$ $\mu \mathrm{g} / \mathrm{ml})$, C. lunata $(125 \mu \mathrm{g} / \mathrm{ml})$ and M. grisea $(250 \mu \mathrm{g} /$ $\mathrm{ml}$ ) (Table 3). The compound eremanthin inhibited the growth of $T$. mentagrophytes $(125 \mu \mathrm{g} / \mathrm{ml}), T$. simii $(62.5$ $\mu \mathrm{g} / \mathrm{ml})$, T. rubrum $296(62.5 \mu \mathrm{g} / \mathrm{ml})$, T. rubrum $57(250$ $\mu \mathrm{g} / \mathrm{ml})$, E. floccosum $(125 \mu \mathrm{g} / \mathrm{ml})$, A. niger $(125 \mu \mathrm{g} / \mathrm{ml})$, C. lunata $(250 \mu \mathrm{g} / \mathrm{ml})$ and M. grisea $(250 \mu \mathrm{g} / \mathrm{ml})$. Both the compounds showed almost similar activities against fungi (Table 2). The lowest MIC values were obtained in costunolide against T. simii at $62.5 \mu \mathrm{g} / \mathrm{ml}$ and $T$. rubrum 296 at $62.5 \mu \mathrm{g} / \mathrm{ml}$. 
Table 1 Minimum inhibitory concentration of different crude extracts of Costus speciosus rhizome against selected bacteria and fungi

\begin{tabular}{|c|c|c|c|c|c|}
\hline \multirow{2}{*}{$\begin{array}{l}\text { Tested organisms } \\
\text { Bacteria }\end{array}$} & \multicolumn{5}{|c|}{ Minimum inhibitory concentration (mg/ml) } \\
\hline & $\mathrm{He}$ & Ch & E.a & Me & W \\
\hline Staphylococcus aureus & 1.25 & 0.625 & 1.25 & 0.625 & $>5$ \\
\hline Staphylococcus epidermidis & 0.625 & 0.312 & 5 & 0.625 & $>5$ \\
\hline Bacillus subtilis & 1.25 & $>5$ & $>5$ & 1.25 & $>5$ \\
\hline Fungi & \multicolumn{5}{|c|}{ Minimum inhibitory concentration $(\mu \mathrm{g} / \mathrm{ml})$} \\
\hline Trichophyton mentagrophytes & 0.62 & 1000 & 0.62 & 1000 & 1000 \\
\hline Epidermophyton floccosum & 0.62 & 1000 & 0.62 & 0.125 & 1000 \\
\hline Trichophyton simii & 0.62 & $>1000$ & 0.62 & 1000 & $>1000$ \\
\hline Trichophyton rubrum 296 & 0.62 & 1000 & 0.125 & 500 & 1000 \\
\hline Trichophyton rubrum 57/01 & 0.125 & 500 & 0.125 & 0.125 & 1000 \\
\hline Curvularia lunata & 500 & 1000 & 0.250 & $>1000$ & $>1000$ \\
\hline Aspergillus niger & 500 & $>1000$ & $>1000$ & $>1000$ & $>1000$ \\
\hline Botrytis cinerea & 1000 & $>1000$ & $>1000$ & $>1000$ & $>1000$ \\
\hline Scopulariopsis sp. & 500 & $>1000$ & $>1000$ & 500 & $>1000$ \\
\hline Magnaporthe grisea & 0.125 & $>1000$ & 1000 & $>1000$ & $>1000$ \\
\hline Candida albicans & $>1000$ & $>1000$ & $>1000$ & $>1000$ & $>1000$ \\
\hline
\end{tabular}

He-Hexane extract; Ch-Chloroform extract; E.a-Ethyl acetate extract; Me -Methanol extract; W-Water extract

\section{Discussion}

Sesquiterpene lactones are the most distinctive secondary metabolites of the members of the Compositae (Asteraceae). However, they have been reported from several plant families, such as Acanthaceae, Amaranthaceae, Apiaceae, Magnoliaceae, Costaceae. They have a diversity of chemical structures and a wide range of biological activities, including antitumourogenic, insect antifeedant, plant growth regulating, antibacterial, antifungal and cytotoxic properties [31-35]. Here we report the antibacterial and antifungal activities of the extracts of $C$. speciosus rhizome. The hexane extract of C. speciosus showed significant antifungal activity. Saraf [36] reported that methanol and aqueous extracts of $C$. specious rhizome did not exhibit any antimicrobial activity against $E$. coli, $S$. aureus, $K$. pnuemoniae, $P$. aeruginosa.
In this study, water extract did not inhibit any tested bacteria; however methanol extract inhibited the growth of Gram-positive bacteria such as S. aureus. S. epidermidis and B. subtilis. Swarnkar and Katewa [37] reported that methanol and water extracts of C. speciosus rhizome inhibited the growth of $S$. aureus $(12 \mathrm{~mm})$. Our study showed that methanol extract inhibited the growth of $S$. aureus $(12 \mathrm{~mm}), S$. epidermidis $(9 \mathrm{~mm}$ ) and B. subtilis $(14 \mathrm{~mm})$. Chen et al. [18] reported that methanol extract of $C$. speciosus showed activity against E. coli, Salmonella enterica and S. aureus.

The isolated compounds, costunolide and eremanthin, significantly inhibited the tested pathogenic fungi at lowest concentrations. Ahmed and Abdelgalei [38] reported that costunolide isolated from Magnolia grandiflora bark showed antifungal activity against plant

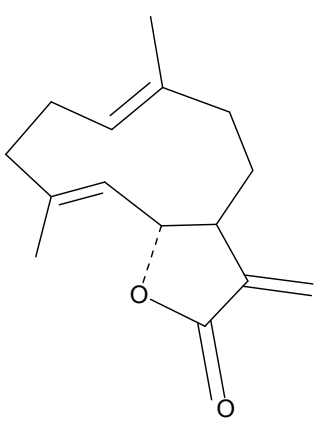

(1)

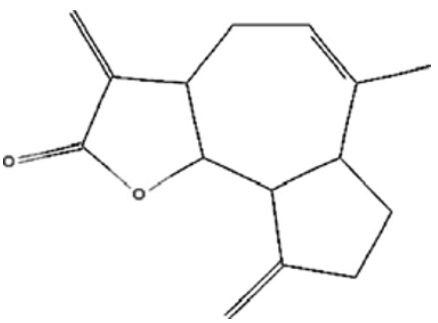

(2)

Figure 1 Costunolide (1) and Eremanthin (2) 
Table 2 Minimum Inhibitory concentrations of costunolide and eremanthin isolated from Costus speciosus against tested fungi using microdilution technique $(\mu \mathrm{g} / \mathrm{ml})$

\begin{tabular}{ccccc}
\hline Tested organisms & Costunolide & Eremanthin & Fluconazole & Ketoconazole \\
\hline Trichophyton mentagrophytes & 62.5 & 125 & 25 & $<12.5$ \\
Trichophyton simii & 31.25 & 62.5 & $<12.5$ & $<12.5$ \\
Trichophyton rubrum 296 & 31.25 & 62.5 & $<12.5$ & $<12.5$ \\
Trichophyton rubrum 57 & 62.5 & 250 & 25 & $<12.5$ \\
Epidermophyton floccosum & 125 & 125 & $<12.5$ & $<12.5$ \\
Scopulariopsis sp. & 250 & $>250$ & 100 & $<12.5$ \\
Aspergillus niger & 250 & 250 & $\mathrm{nt}$ & $\mathrm{n}$ \\
Curvularia lunata & 125 & 250 & $\mathrm{nt}$ & $\mathrm{nt}$ \\
Magnaporthe grisea & 250 & $>250$ & $>100$ & $\mathrm{nt}$ \\
Botrytis cinerea & $>250$ & $>250$ & 25 \\
Candida albicans & $>250$ & & \\
\hline
\end{tabular}

nt-not Tested

Fluconazole, Ketoconazole-standard antifungal agent

Costunolide, Eremanthin-Isolated compound

pathogenic fungi. They found that costunolide showed higher antifungal activity than the reference control.

The present study also showed costunolide inhibited the growth of tested fungi better than eremanthin. Both the compounds were isolated using low polar solvent (hexane). Barrero et al. [39] stated that low polar sesquiterpene lactones showed more potent antifungal activity. It is well known that the presence of $\alpha$-methylene- $\gamma$-lactone is essential for potent antifungal activity of sesquiterpene lactones. The low polarity of these compounds matches with optimum lipophilic characteristics required for passing through the fungal cell wall [38].

Antifungal activity of steroid saponins and sapogenins from C. speciosus was analyzed previously by Singh et $a l$. [40] on six species of plant pathogenic fungi at different concentrations. Saponin B was found to be highly effective against conidial germination of Botrytis cineria and Alternaria sp.

p-Coumaric acid methyl ester was found in the rhizome of $C$. speciosus as a constitutive principle with antifungal activity against plant pathogenic fungi Cladosporium cladosporioides, Colletotrichum gleosporioides, Curvularia sp. and Penicillium sp. [41]. Moreira et al. [42] have reported that sesquiterpenoids (aromadendrane-4 $\beta, 10 \alpha, 15$-triol) isolated from the leaves of Xylopia brasiliensis showed activity against Cladosporium cladosporioides. In our study costunolide and eremanthin showed good antifungal activity.

\section{Conclusion}

A thorough analysis of the results indicated that among the extracts of $C$. speciosus, only the hexane extract showed moderate activity against tested bacteria and promising activity against fungi. Two compounds, costunolide and eremanthin, were isolated from the hexane extract of C. speciosus with significant antifungal activity in vitro. This is the first report for the antifungal activity of costunolide and eremanthin against dermatophytes.

\section{Acknowledgements}

Authors are thankful to the Entomology Research Institute, Loyola College, Chennai-600 056, India and Addiriyah Chair for Environmental Studies, Department of Botany and Microbiology, College of Science, King Saud University, Saudi Arabia for financial assistance.

\section{Author details}

'Department of Botany and Microbiology, Addiriyah Chair for Environmental Studies, College of Science, King Saud University, P. O. Box 2455, Riyadh 11451, Saudi Arabia. ${ }^{2}$ Division of Ethnopharmacology, Entomology Research Institute, Loyola College, Chennai 600 034, India.

\section{Authors' contributions}

VD and CM carried out the study; VD designed the experiments and wrote the manuscript; SI and NAAH supervised the work; all authors read and approved the final manuscript.

\section{Competing interests}

The authors declare that they have no competing interests.

Received: 23 November 2011 Accepted: 7 March 2012

Published: 7 March 2012

\section{References}

1. Okeke IN, Laxmaninarayan R, Bhutta ZA, Duse AG, Jenkins $P$, O'Brien TF, Pablos-Mendez A, Klugman KP: Antimicrobial resistance in developing countries. Part 1: recent trends and current status. Lancet Infect Dis 2005, 5:481-493

2. Chopra RN, Nayer SL, Chopra IC: Glossary of Indian Medicinal Plants. 3 edition. New Delhi: Council of Scientific and Industrial Research; 1992, 7-246, ISBN.

3. Eliza J, Daisy P, Ignacimuthu S, Duraipandiyan V: Normo-glycemic and hypolipidemic effect of costunolide isolated from Costus speciosus (Koen ex. Retz.)Sm. in streptozotocin-induced diabetic rats. Chem Biol Interact 2009, 179:329-334.

4. Tushar Basak S, Sarma GC, Rangan L: Ethnomedical uses of Zingiberaceous plants of Northeast India. J Ethnopharmacol 2010, 132:286-296.

5. Khare CP: Indian Medicinal Plants: an Illustrated Dictionary Published by Springer-Verlag Berlin/Heidelberg; 2007, 181-182. 
6. Chopra RN, Nayar SL, Chpora IC: Glossary of Indian Medicinal Plants National Institute of Science Communication and Information Resources, CSIR, New Delhi, India; 2006, 79.

7. Gupta RK: In Medicinal and Aromatic Plants. Volume 234.. 1 edition. CBS Publishers and Distributors, New Delhi, India; 2010:499.

8. Nadkarni KM: In Indian Materia Medica. Volume 1.. 3 edition. Bombay Popular Prakashan; 2009:21.

9. Anonymous: In The Wealth of India: First Supplement Series (Raw Materials). Volume 2. National Institute of Science Communication and Information Resources, CSIR, New Delhi, India; 2007:211-213.

10. Deni B: Encyclopaedia of Herbs and their uses The Royal Horticulture Society, London, UK; 2008, 181

11. Mohamad S, Zin NM, Wahab HA, Ibrahim P, Sulaiman SF, Zahariluddin ASM, Noor SSM: Antituberculosis potential of some ethnobotanically selected Malaysian plants. J Ethnopharmacol 2011, 133:1021-1026.

12. Pattanaik C, Reddy CS, Murthy MSR: An ethnobotanical survey of medicinal plants used by the Didayi tribe of Malkangiri district of Orissa, India. Fitoterapia 2008, 79:67-71.

13. Vijayalakshmi MA, Sarada NC: Screening of Costus speciosus extracts for antioxidant activity. Fitoterapia 2008, 79:197-198.

14. Bhattacharya SK, Parikh AK, Debnath PK, Pandey VB, Neogy N: Pharmacological studies with the alkaloids of Costus speciosus (kemuka). J Res Indian Med 1973, 8:10-19.

15. Srivastava S, Singh P, Mishra G, Jha KK, Khosa RL: Costus speciosus (Keukand): A review. Der Pharmacia Sinica 2011, 2:118-128.

16. Gupta MM, Verma RK, Akhila A: Oxo acids and branched fatty acid esters from rhizomes of Costus speciosus. Phytochemistry 1986, 25:1899-1902.

17. Yamahara J, Kobayashi M, Miki K, Kozuka M, Sawada T, Fujimura H: Cholagogic and antiulcer effect of Saussureae radix and its active components. Chem Pharm Bull 1985, 33:1285-1288.

18. Chen H, Chou C, Lee S, Wang J, Yeh S: Active compounds from Saussurea lappa Clarks that suppress hepatitis B virus surface antigen gene expression in human hepatoma cells. Antiviral Res 1995, 27:99-109.

19. Taniguchi M, Kataoka T, Suzuki H, Uramoto M, Ando M, Magae J, Nishimura T, Otake N, Nagai K: Costunolide and dehydrocostus lactone as inhibitors of killing function of cytotoxic T lymphocytes. Biosci Biotechnol Biochem 1995, 59:2064-2067.

20. Furuya $Y$, Lundmo P, Short AD, Gill DL, Isaacs JT: The Role of Calcium, $\mathrm{pH}$, and Cell Proliferation in the Programmed (Apoptotic) Death of Androgenindependent Prostatic Cancer Cells Induced by Thapsigargin. Cancer Res 1994, 54:6167-6175.

21. Woynarowski JM, Napier C, Koester SK, Chen SF, Troyer D, Chapmen W, Macdonald JR: Effects on DNA integrity and apoptosis induction by a novel antitumor sesquiterpene drug, 6-hydroxymethylacylfulvene (HMAF, MGI 114). Biochem Pharmacol 1997, 54:1181-1193.

22. Mori H, Kawamori T, Tanaka T, Ohnishi M, Yamahara J: Chemopreventive effect of costunolide, a constituent of oriental medicine, on azoxymethane-induced intestinal carcinogenesis in rats. Cancer Lett 1994, 83:171-175.

23. Mastuda H, Shimoda H, Uemura T, Yoshikawa M: Preventive effect of seequiterpenes from bay leaf on blood ethanol elevation in ethanol loaded rat: Structure requirement and suppression of gastric emptying. Bioorg Med Chem Lett 1999, 9:2647-2652.

24. Yoshikawa M, Shimoda H, Uemura T, Morikawa T, Kawahara Y, Mastuda H: Alcohol absorbtion inhibitors from bay leaf (Laurus nobilis: Structure requirements of sesquiterpenes for the activity. Bioorg Med Chem Lett 2000, 8:2071-2077.

25. Fda LD, Takahashi CS, Sakamoto-Hojo E, Vichnewski W, Sarti SJ: Genotoxicity of the natural cercaricides "sucupira" oil and eremanthine in mammalian cells in vitro and in vivo. Environ Mol Mutagen 1995, 26:338-344.

26. Filomena C, Giancarlo S, Dimitar U, Francesco M: Comparative chemical composition and antioxidant activities of wild and cultivated Laurus nobilis L. leaves and Foeniculum vulgare sub sp. piperitum (Ucria) coutinho seeds. Biol Pharm Bull 2006, 29:2056.

27. Daisy P, Eliza J, Ignacimuthu S: Influence of Costus speciosus (Koen.)Sm. Rhizome extracts on biochemical parameters in STZ induced Diabetic rats. J Health Sci 2008, 54:675-681.

28. Eliza J, Daisy P, Ignacimuthu S, Duraipandiyan V: Antidiabetic and antilipidemic effect of eremanthin from Costus speciosus (Koen.)Sm., in STZ-induced diabetic rats. Chem Biol Interact 2009, 182:67-72.
29. Eliza J, Daisy P, Ignacimuthu S: Antioxidant activity of costunolide and eremanthin isolated from Costus speciosus (Koen ex. Retz) Sm. Chem Biol Interact 2010, 188:467-472.

30. Duraipandiyan $V$, Ignacimuthu S: Antibacterial and antifungal activity of Flindersine isolated from Toddalia asiatica (L) Lam. a traditional medicinal plant. J Ethnopharmacol 2009, 123:494-498.

31. Picman AK: Biological activities of sesquiterpenes. Biochem System Biol 1986, 14:255-281.

32. Baruah NC, Sarma JC, Barua NC, Sarma S, Sharma RP: Germination and growth inhibitory sesquiterpene lactones and a flavone from Tithonia diverifolia. Phytochemistry 1994, 36:29-33.

33. Goren N, Woerdenbag HJ, Bozok-Johansson C: Cytotoxic and antibacterial activities of sesquiterpene lactones isolated from Tanacetum praeteritum subsp praeteritum. Planta Med 1994, 62:419-422.

34. Mansilla H, Palenzuela JA: Minor eudesmanolides from Artemisia canariensis. Phytochemistry 1999, 51:995-997.

35. Neerman MF: Sesquiterpene lactones: a diverse class of compounds found in essential oils possessing antibacterial and antifungal properties. Int J Aromather 2003, 13:114-120.

36. Saraf A: Phytochemical and Antimicrobial Studies of Medicinal Plant Costus Speciosus (Koen.). E-J Chem 2010, 7:405-413, ISSN: 0973-4945; CODEN ECJHAO.

37. Swarnkar S, Katewa SS: Antimicrobial activities of some tuberous medicinal plants from Aravalli hills of Rajasthan. J Herbal Med Toxicol 2009, 3:53-58.

38. Ahmed SM, Abdelgalei SAM: Antifungal activity of extracts and sesquiterpene lactones from Magnolia grandiflora L. (Magnoliaceae). Int $J$ Agr Biol 2005, 7:638-642.

39. Barrero AF, Oltra JE, Alvarez M, Raslan DS, Saude DA, Akssira M: New sources and antifungal activity of sesquiterpene lactones. Fitoterapia 1988, 71:60-64.

40. Singh UP, Srivsastava BP, Singh KP, Pandey VB: Antifungal activity of steroid saponins and sapogenins from Avena sativa and Costus speciosus. Naturalia Sao Paulo 1992, 17:71-77.

41. Bandara RBM, Hewage CM, Karunaratne V, Adikaram NKB: Methyl ester of para-coumaric acid: Antifungal principle of the rhizome of Costus speciosus. Planta Med 1988, 54:477-478.

42. Moreira IC, Lago JHG, Young MCM, Roque NF: Antifungal Aromadendrane Sesquiterpenoids from the Leaves of Xylopia brasiliensis. J Braz Chem Soc 2003, 14:828-831.

\section{Pre-publication history}

The pre-publication history for this paper can be accessed here: http://www.biomedcentral.com/1472-6882/12/13/prepub

doi:10.1186/1472-6882-12-13

Cite this article as: Duraipandiyan et al: Antimicrobial activity of sesquiterpene lactones isolated from traditional medicinal plant, Costus speciosus (Koen ex.Retz.) Sm. BMC Complementary and Alternative Medicine 2012 12:13.

\section{Submit your next manuscript to BioMed Central and take full advantage of:}

- Convenient online submission

- Thorough peer review

- No space constraints or color figure charges

- Immediate publication on acceptance

- Inclusion in PubMed, CAS, Scopus and Google Scholar

- Research which is freely available for redistribution 